\title{
COMPARATIVE STUDY ON BIOACCUMULATION AND TRANSLOCATION OF METALS IN BERMUDA GRASS (CYNODON DACTYLON) NATURALLY GROWING ON FLY ASH LAGOON AND TOPSOIL
}

\author{
MAITI, S. K..$^{1 *}$ KUMAR, A. ${ }^{2}-$ AHIRWAL, J. ${ }^{1}-$ DAS, R. ${ }^{1}$ \\ ${ }^{I}$ Department of Environmental Science and Engineering \\ Centre of Mining Environment \\ Indian School of Mines \\ Dhanbad-826004, Jharkhand, India \\ ${ }^{2}$ Department of Plant Physiology and Biochemistry, Institute of Natural Sciences, \\ Ural Federal University, Ekaterinburg, Russia 620000 \\ (phone: +91-326-2235467 (O); +91-326-223-2235567(R); mobile: +91-947-1191278; \\ central fax-+91-326-2296563) \\ *Corresponding author \\ email:subodh_maiti@yahoo.com \\ (Received $9^{\text {th }}$ Oct 2014; accepted $30^{\text {th }}$ Sept 2015)
}

\begin{abstract}
Cynodon dactylon (Bermuda grass) is one of the most common naturally colonized creeper grass found on fly ash lagoons and soils in India. Bioavailable metal concentrations in fly ash and topsoil were analyzed by using DTPA as extractant. Bioaccumulation of metals in the root and their translocation to the shoot were estimated for fly ash and compared with topsoil. Bioaccumulation of $\mathrm{Zn}, \mathrm{Mn}, \mathrm{Ni}$ and $\mathrm{Cu}$ were found similar for the plants growing on fly ash and topsoil. Different bioaccumulation trends were observed for $\mathrm{Pb}, \mathrm{Co}$ and $\mathrm{Cd}$, in fly ash and topsoil. In fly ash translocation factors were found $>1$ for $\mathrm{Cd}$, $\mathrm{Mn}, \mathrm{Zn}$ and $\mathrm{Cu}$, indicating a higher translocation of these metals in aerial parts, which can easily transfer to the food chain. In topsoil, translocation factor for all the metals (except $\mathrm{Cd}$ ) was found $<1$, indicating immobilization of metals in root. The study concluded that Bermuda grass growing on fly ash lagoons can act as a transferring link of heavy metals in the food chain.
\end{abstract}

Keywords: Cynodon dactylon, fly ash, bioconcentration factor, mobility ratio, translocation factor, heavy metals

\section{Introduction}

Nearly $75 \%$ of India's total power generation capacity is thermal, of which $90 \%$ power generation is based on coal. High ash content in the range of 30 to $50 \%$ in Indian coal is the major cause for voluminous generation of coal ash (FAU, 2013). The generation of one megawatt (MW) power with Indian coal (average ash content 35\%) results in co-generation of nearly 1800 tonnes $(t)$ of ash, out of which, nearly $20 \%$ is coarser bottom ash and about $80 \%$ (1500t) is fly ash (FA) collected through electro static precipitators (ESPs). In India, present generation of FA is about 160 million tonnes (Mt) per year, which is expected to be 300 and $700 \mathrm{Mt} /$ year by 2016-17 and 2031-32, respectively.

Out of $160 \mathrm{Mt} \mathrm{FA}$, about $55.8 \%$ is reused, and rest is stored in FA lagoons occupying more than 70,000 acres of land (Verma, et al, 2015). It is estimated that about $1500 \mathrm{Mt}$ of FA is already accumulated in ash ponds and probably $70 \%$ of FA being produced worldwide is disposed of in landfills (Haynes, 2009). It is reported that by 2015, FA 
storage would require about $3235 \mathrm{~km}^{2}$ of land worldwide (Pandey and Singh, 2012). The FA lagoons invite several environmental problems, like complete change in landcsape and aesthetics of the area, increase in dust pollution during summer season, ground water contamination and water pollution during monsoon and bioaccumulation of metals in the plants and subsequent transfer to trophic level (Maiti and Jaiswal, 2008, Haynes, 2009). There are two major constraints faced by coal based thermal power plants (TTPs): (a) land requirement for the FA disposal site, and (b) prevents pollution from the FA disposal site, because very fine FA particles are easily airborne during summer causing air pollution while during monsoon huge quantity is eroded causing contamination of soil and water. Hence, to prevent pollution problems, topsoil blanketing of FA lagoons is the most viable alternative for the developing countries.

FA occurs as spherical particles of alumino-silicate glass usually ranging in diameter of 1$100 \mu \mathrm{m}$, more precisely ranged from $3.90-71.13 \mu \mathrm{m}$ (Verma et al, 2015). Moreover, when compared with topsoil (TS), FA has a lower bulk density, hydraulic conductivity, specific gravity, higher concentration of $\mathrm{Ca}, \mathrm{K}, \mathrm{Na}$ and $\mathrm{Mg}$, with an anomalous concentration of trace metals $(\mathrm{Cu}, \mathrm{Zn}, \mathrm{Mn}, \mathrm{Co}, \mathrm{Ni}, \mathrm{Pb}, \mathrm{Cd}$, Se, etc.) and radioactive elements (Maiti and Jaiswal, 2008). Poor physical characteristics, low nutrient contents along with elevated metal concentration creates unfavorable condition for the deep-rooted plant establishment (Mukhopadhyay and Maiti, 2010). Rather, in most of the FA lagoons, natural vegetation grwoth is scanty, consists of hardy tuft grasses (Saccharum munja, S. officinalis), creepers (C. dactylon, Cyperus spp, Evolvulus spp.), herbs and shallow rooted xeric shrubs (Calotropis, Croton etc) (Maiti and Jaiswal, 2008; Pandy and Singh, 2012).

There has been less reported research on the extent of metal accumulation and translocation by grass species growing on FA lagoons as compared to TS. Cynodon dactylon (L.) pers. is a perennial, widespread creeping grass, naturally colonizes in extreme habitat of FA lagoons. Research studies are mainly focused on, use of $C$. dactylon to restore and enhance the productivity of abandoned sodic lands (Gupta et al., 2002; Singh et al., 2013); accumulation of $\mathrm{Ni}$ and $\mathrm{Pb}$ from contaminated soils (Soleimani et al., 2009). Accumulation of metals in $C$. dactylon grown of refused-compost-amended soil studied by Wong and Chu (1985) and reported higher concentration of $\mathrm{Cu}, \mathrm{Cd}$ and $\mathrm{Zn}$ in roots than aerial parts, while contents of $\mathrm{Cd}, \mathrm{Mn}$ and $\mathrm{Zn}$ were higher in the foliage of second harvest than the first one. Sainger et al. (2011) studied the heavy metal tolerance of $C$. dactylon growing on effluent discharge from electroplating industry and found bioaccumulation and translocation factor in order of $\mathrm{Zn}>\mathrm{Fe}>\mathrm{Cu}>\mathrm{Ni}>\mathrm{Cr}$.

Development of vegetation covers on FA is essential to control environmental menace (China et al., 2014), however, without soil blanketing, it is not possible. Blanketing with soil will not only reduce environmental pollution but also provide suitable substrate for vegetation growth and promotes plant succession. Several invasive species naturally colonized on the early stages of succession and remains occupied permanently. In Indian context, $C$. dactylon which is a perennial, and palatable fodder for cattle was found growing on the FA lagoon. In addition, the grass can tolerate a wide range of $\mathrm{pH}$ and temperature, strong resistance to drought, resilient turf could easily control airborne suspension of FA. Therefore, the present study focused on the estimation of metal concentrations in TS and weathered FA and assessment of bioconcentration and translocation factor as indicators for plants potential for phytoremedation. 


\section{Materials and methods}

\section{Collection and analysis of fly ash, topsoil and plant samples}

The FA and TS samples were collected from the surface layer $(0-15 \mathrm{~cm})$ of FA lagoon and nearby undisturbed site (control site) located at the Chardrapura Thermal Power Plant $\left(23^{\circ} 75^{\prime} \mathrm{N}, 86^{\circ} 12^{\prime} \mathrm{E}\right)$, Jharkhand, India (Fig. 1). Five-replicate samples were collected and mixed thoroughly to obtain a composite sample by using the ConingQuartering method (Maiti, 2013). Sample volume was reduced approximately to $500 \mathrm{~g}$, placed in a plastic bag and labeled.

In the laboratory, the FA and TS samples were air dried at room temperature $\left(30-35^{\circ} \mathrm{C}\right)$ for one week then homogenized by grinding in a stainless steel grinder and passed through a $2 \mathrm{~mm}$-sieve for further analyses. The $\mathrm{pH}$ and electrical conductivity (EC) were determined by $\mathrm{pH}$ meter and Conductivity meter, respectively in a 1:2.5 ratio (soil-to-water suspension after stirring for $2 \mathrm{~h}$ ) (Jackson, 1973). The organic carbon was determined using rapid dichromate method and organic matter was calculated by multiply with a factor of 1.72 (Walkley and Black 1934), available nitrogen $\left(\mathrm{NH}_{4}-\mathrm{N}\right)$ determined through alkaline potassium permanganate method (Keeny and Bremer, 1966), exchangeable $\mathrm{Na}, \mathrm{K}$, $\mathrm{Ca}$ and Mg were extracted by neutral $1 \mathrm{~N}$ ammonium acetate $(1: 10 ; \mathrm{w} / \mathrm{v}$, soil:water) and determined by flame photometer (Maiti, 2003). Bioavailable (DTPA- extractable) metals from FA and TS were extracted by using 0.005M DTPA extractant (Lindsay and Norvell, 1978; Alloway, 1990). Heavy metal in plant samples were analysed as per the method followed by Kumar and Maiti (2014). All the extracts were analyzed in the atomic absorption spectrophotometer (AAS, GBC Avanta, Australia).

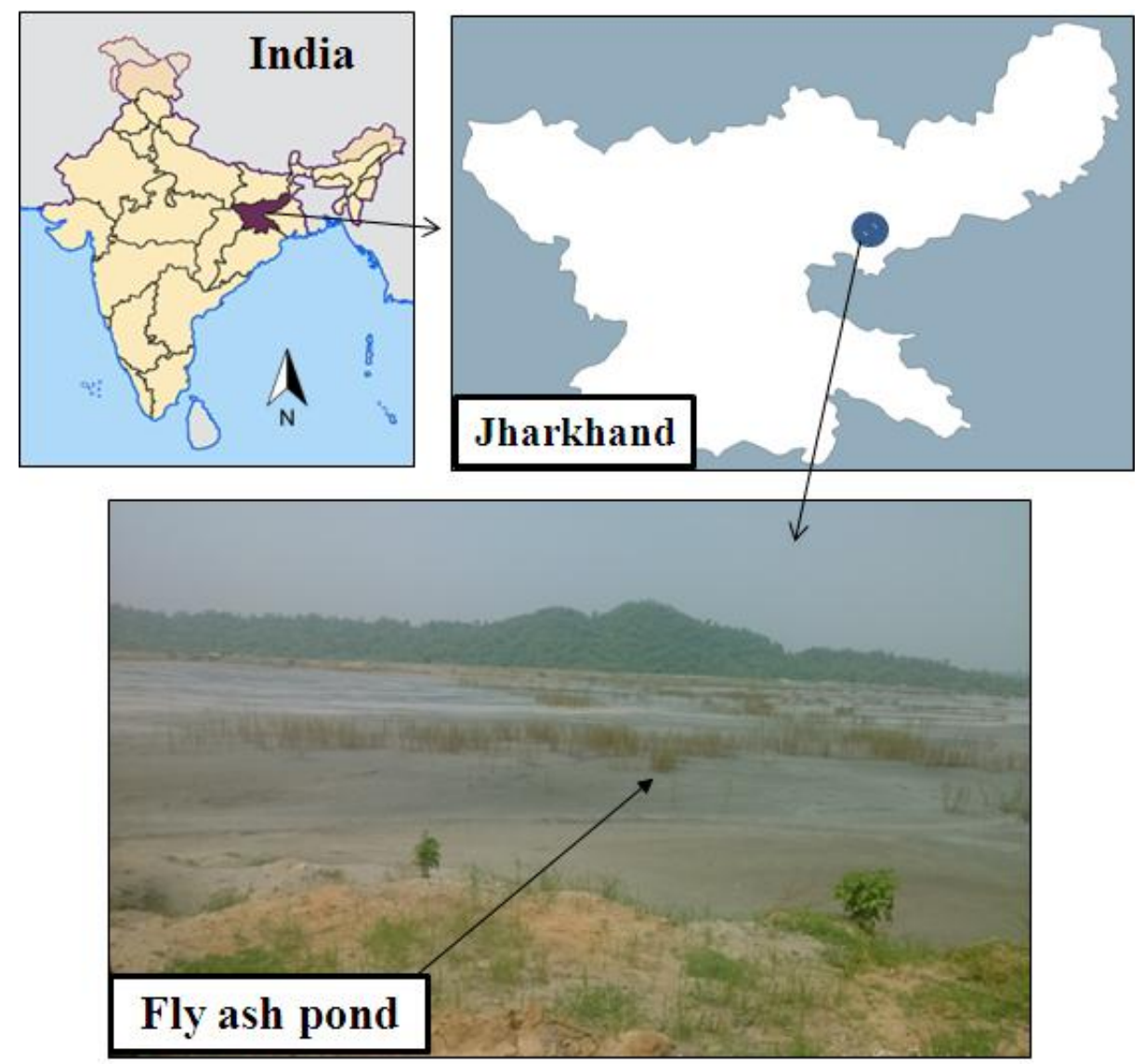

Figure 1. Location of Chandrapura thermal power plant and the fly ash lagoon 
For quality assurance and quality control (QA/QC), care was taken during sample collection and analysis. Analytical grade reagents and calibrated glasswares were used for all the analysis. Reagent blanks, duplicates, and spiked samples were used during the analysis of metals. Standard Reference Materials (AccuTrace, AccuStandard Inc, USA; Matrix 2-5\% Nitric acid; CRM uncertainty $\pm 5 \%$; verified against NIST) were used for the preparation and calibration of each analytical batch. Duplicate analysis for the seven analyzed metals showed agreement levels ranging from $75.4 \%$ to $97.3 \%$. The recoveries of metal spiked-samples ranged from $94 \%$ to $107 \%$. Calibration coefficients were maintained at a high level $\geq 0.999$. The detection limits for the metals under the study were ranged between $0.01-0.05 \mathrm{mg} \mathrm{kg}^{-1}$.

\section{Biological indices}

Biological indices provide a good assessment tool for determination of plant-metal interaction in the different metal contaminated substrates. Most popularly used biological indices are as follows (Lindsay and Norvell, 1978; Maiti and Jaiswal, 2008; Gakwavu, et al., 2012):

1. Bioconcentration factor $(\mathrm{BCF})$ indicates metal uptake by the plant from the fly ash or soil.

$$
\mathrm{BCF}=\frac{\text { Concentration of metal in root, } \mathrm{mg} \mathrm{kg}^{-1}}{\text { Concentration of metal (DTPA extractable) in fly ash or soil, } \mathrm{mg} \mathrm{kg}^{-1}}
$$

2. Mobility ratio (MR), also known as the biological accumulation coefficient (BAC), calculated as the ratio of metal concentration in the aerial parts of the plant to those in fly ash or soil:

$$
\mathrm{MR}=\frac{\text { Concentration of metal in shoot, } \mathrm{mg} \mathrm{kg}^{-1}}{\text { Concentration of metal (DTPA extractable) in fly ash or soil, } \mathrm{mg} \mathrm{kg}^{-1}}
$$

3. Translocation factor (TF) indicates plant's ability to translocate metal from root to aerial part. TF $>1$ indicates that plant translocate metals effectively from root to shoot (Maiti and Nandhini 2006; Sanghamitra et al., 2012):

$$
\mathrm{TF}=\frac{\text { Concentration of metal in shoot, } \mathrm{mg} \mathrm{kg}^{-1}}{\text { Concentration of metal in root, } \mathrm{mg} \mathrm{kg}^{-1}}
$$

\section{Statistical analyses}

Mean, standard deviation, student t-test and regression analysis were carried out using MS-Excel 2007 (Microsoft Inc.). 


\section{Results and discussion}

A large quantity of ash has to be stored in FA lagoons, particularly for those countries, which are depends of high ash coal (30-40\%) for power generation. FA contain anomalous concentration of heavy metals and causes recurring threat to the surrounding environment. Phytostabilisation of FA lagoons by developing vegetation cover is the best techno-economically viable method, which could be facilitated by blanketing with soil. Once FA lagoon covered with soil, it will promote recruitment of diverse autochthonous species as "pioneer species", such as $C$. dactylon.

The concentration of total metals in FA depends on the source and type of coal, occurrence of the elements and their association with inorganic and organic components of coal, power plant operating conditions, volatilization- condensation mechanisms and particle size of the ash. A comparison of total metal concentrations in FA of the presnt study with other FA produced by some Indian TPPs are given in Table.1. Generally, higher concentration of trace metals in FA than coal is due to the enrichment of trace metals during combustion process. Enrichment factor ( $\mathrm{EF}=$ concentration of metals in FA/ concentration of metals in coal) for different metals in FA reported as: $\mathrm{Zn}(\mathrm{EF}:$ 9.28) $>\mathrm{Cu}$ (7.35)> $\mathrm{Ni}(7.09)>\mathrm{Pb}(5.44)>\mathrm{Co}$ (4.51)> $\mathrm{Mn}$ (2.57)> Cd (1.87) (Verma et al., 2015).

Table 1. Total metal concentration in fly ash of Indian thermal power plants (TPPs).

\begin{tabular}{|c|c|c|c|c|c|c|c|c|}
\hline \multirow{2}{*}{$\begin{array}{l}\text { Locations of } \\
\text { TPPs in India }\end{array}$} & \multicolumn{7}{|c|}{ Metal concentration $\left(\mathrm{mg} \mathrm{kg}^{-1}\right)$} & \multirow{2}{*}{ References } \\
\hline & $\mathrm{Mn}$ & $\mathrm{Zn}$ & $\mathrm{Cu}$ & $\mathrm{Ni}$ & $\mathrm{Cd}$ & $\mathrm{Pb}$ & $\mathrm{Co}$ & \\
\hline $\begin{array}{l}\text { NLC, } \\
\text { Tamilnadu }\end{array}$ & 177.5 & 15.7 & 46.1 & 130.8 & 11.1 & 15.1 & 21.7 & $\begin{array}{l}\text { Ram et al. } \\
(2007)\end{array}$ \\
\hline $\begin{array}{l}\text { Santaldih, West } \\
\text { Bengal }\end{array}$ & 328.0 & 44.2 & 24.3 & 21.0 & 2.0 & 16.8 & 0.5 & $\begin{array}{l}\text { Maiti and } \\
\text { Jaiswal } \\
\text { (2008) }\end{array}$ \\
\hline $\begin{array}{l}\text { NTPC, Tanda } \\
\text { Uttar Pradesh }\end{array}$ & 69.4 & 82.3 & 58.4 & 204.9 & 40.3 & 40.2 & na & $\begin{array}{l}\text { Pandey et al. } \\
\text { (2009) }\end{array}$ \\
\hline $\begin{array}{l}\text { NTPC Anpara, } \\
\text { Uttar Pradesh }\end{array}$ & 60.0 & 57.7 & 65.8 & 44.8 & 13.4 & 20.0 & 21.1 & $\begin{array}{l}\text { Tripathi et al. } \\
\text { (2009) }\end{array}$ \\
\hline $\begin{array}{l}\text { NTPC } \\
\text { Unchahar, } \\
\text { Uttar Pradesh }\end{array}$ & 180.0 & 53.0 & 45.8 & 11.7 & 1.4 & 44.1 & 3.9 & $\begin{array}{l}\text { Verma et al. } \\
(2015)\end{array}$ \\
\hline $\begin{array}{l}\text { DVC } \\
\text { Chardrapura, } \\
\text { Jharkhand }\end{array}$ & 130.0 & 26.7 & 30.8 & 19.8 & 1.3 & 17.3 & 0.5 & Present study \\
\hline
\end{tabular}

The selective physicochemical properties of the FA and TS samples are given in Table 2. The $\mathrm{pH}$ of FA was acidic with an average value of 6.17 and the average electrical conductivity was recorded as $97.43 \mu \mathrm{S} \mathrm{cm}^{-1}$. The $\mathrm{pH}$ of FA was circumneutral and EC value was lower as compared to the other similar studies in India that may attribute to the cations and acid generating components in the FA and leaching and weathering process in which ions are leached to lower depth. Bulk density of FA was unfavorable for the plant growth $\left(0.89 \mathrm{Mg} \mathrm{m}^{-3}\right)$.

FA was deficient in organic carbon and available $\mathrm{N}$ content than TS. Low organic carbon content in the FA may be attributed to the absence of the plant litter (Singh et al., 2013). 
Available $\mathrm{N}$ content in the FA was found less than $10 \mathrm{mg} \mathrm{kg}^{-1}$ due to the low level of microbial activity and low rate of mineralization (Ram et al., 2007). Low cation value was observed in the FA as compared to the topsoil due to the leaching and weathering of the FA.

The bioavailable metals concentration in weathered FA were found in the order of $\mathrm{Mn}>\mathrm{Zn}>\mathrm{Cu}>\mathrm{Ni}>\mathrm{Pb}>\mathrm{Cd}>\mathrm{Co}$ (Table 2). The amount of bioavailable $\mathrm{Cu}, \mathrm{Ni}, \mathrm{Pb}$ and $\mathrm{Cd}$ were significantly higher in the FA compared to the adjacent TS. However, the environmental conditions, which influence the mobility and availability of metals to the plant species, may modify the toxicity threshold.

Table 2. Physicochemical characteristic of the fly ash and topsoil (Mean $\pm S D)$.

\begin{tabular}{|c|c|c|c|}
\hline Parameter & Fly $\operatorname{ash}(\mathbf{n}=9)$ & Topsoil $(n=9)$ & t-value \\
\hline $\mathrm{pH}(1: 2.5, \mathrm{w} / \mathrm{v})$ & $6.17 \pm 0.29$ & $5.92 \pm 0.52$ & $1.57 *$ \\
\hline Electrical conductivity $\left(\mu \mathrm{S} \mathrm{cm}^{-1}\right)$ & $97.43 \pm 62.8$ & $81.46 \pm 35.8$ & $0.82 *$ \\
\hline Bulk density $\left(\mathrm{Mg} \mathrm{m}^{-3}\right)$ & $0.89 \pm 0.02$ & $1.45 \pm 0.10$ & $21.34 * *$ \\
\hline Organic matter $(\%)$ & $0.84 \pm 0.40$ & $1.07 \pm 0.25$ & $1.03 *$ \\
\hline Available $\mathrm{N}\left(\mathrm{mg} \mathrm{kg}^{-1}\right)$ & $<10$ & $65.50 \pm 9.96$ & $21.94 * *$ \\
\hline \multicolumn{4}{|c|}{ Exchangeable bases [cmol (p+) $\left.\mathrm{kg}^{-1}\right]$} \\
\hline $\mathrm{Na}$ & $0.29 \pm 0.09$ & $0.59 \pm 0.31$ & $3.44 * *$ \\
\hline $\mathrm{K}$ & $0.37 \pm 0.12$ & $0.27 \pm 0.10$ & $2.52 * *$ \\
\hline $\mathrm{Ca}$ & $3.65 \pm 0.61$ & $19.5 \pm 7.04$ & $8.41 * *$ \\
\hline $\mathrm{Mg}$ & $2.04 \pm 0.97$ & $9.50 \pm 2.73$ & $5.24 * *$ \\
\hline Cation exchange capacity (CEC) & $6.45 \pm 1.18$ & $19.86 \pm 2.18$ & $20.26 * *$ \\
\hline $\mathrm{Ex} \mathrm{Ca/} \mathrm{Ex} \mathrm{Mg} \mathrm{ratio}$ & 1.79 & 2.05 & - \\
\hline \multicolumn{4}{|c|}{ Bioavailable trace element (DTPA extractable; $1: 2, w / v)\left(\mathrm{mg} \mathrm{kg}^{-1}\right)$} \\
\hline $\mathrm{Mn}$ & $4.16 \pm 2.31$ & $18.20 \pm 5.74$ & $8.48 * *$ \\
\hline $\mathrm{Zn}$ & $2.35 \pm 0.47$ & $2.24 \pm 0.59$ & $0.55^{*}$ \\
\hline $\mathrm{Cu}$ & $1.14 \pm 0.20$ & $0.67 \pm 0.13$ & $7.25 * *$ \\
\hline $\mathrm{Ni}$ & $0.82 \pm 0.17$ & $0.54 \pm 0.13$ & $4.92 * *$ \\
\hline $\mathrm{Pb}$ & $0.56 \pm 0.08$ & $0.46 \pm 0.08$ & $3.58 * *$ \\
\hline $\mathrm{Cd}$ & $0.34 \pm 0.04$ & $0.31 \pm 0.06$ & $1.17 *$ \\
\hline Co & $<0.05$ & $<0.05$ & - \\
\hline
\end{tabular}

** Significantly different at $\mathrm{p}<0.05 ; *$ no significant difference at $\mathrm{p}<0.05$

Accumulation of metals in root and shoot parts of $C$. dactylon growing on FA and TS are shown in Table 3. Metal accumulation patterns in $C$. dactylon on FA were found in the order of $\mathrm{Zn}>\mathrm{Ni}>\mathrm{Pb}>\mathrm{Cu}>\mathrm{Mn}>\mathrm{Cd}$ whereas in $\mathrm{TS}$ it was $\mathrm{Zn}>\mathrm{Ni}>\mathrm{Cu}>\mathrm{Cd}$ $>\mathrm{Mn}>\mathrm{Pb}$. Only two metals ( $\mathrm{Zn}$ and $\mathrm{Mn}$ ) were found be accumulated in highest concentration in $C$. dactylon growing on FA and TS, however, different accumulation patters were observed for four other metals $(\mathrm{Pb}, \mathrm{Cu}, \mathrm{Mn}$ and $\mathrm{Cd})$. Higher accumulation 
of metals found in roots compared to shoots indicates the restricted translocation in the aerial part of $C$. dactylon. The BCF and TF largely depend on the $\mathrm{pH}$ conditions of the growing media (TS or FA).

While comparing metal concentration in $C$. dactylon in FA and TS, root tissue $\mathrm{Mn}$ concentration in FA was much lower than TS, while in shoot same concentration was observed (33-34 $\mathrm{mg} \mathrm{kg}^{-1}$ ). Even though FA has lower level of bioavailable $\mathrm{Mn}$, being a micronutrient, the desire level of $\mathrm{Mn}$ was found to be translocated to the shoots. The tissue Mn concentration of $C$. dactylon reported as $55.8 \mathrm{mg} \mathrm{kg}^{-1}$ (Madejon et al., 2002). Other micronutrient, tissue $\mathrm{Zn}$ concentration was same for FA and TS in the order of $67-87 \mathrm{mg} \mathrm{kg}^{-1}$. Shu et al. (2002) also reported $\mathrm{Zn}$ concentration of $C$. dactylon growing in normal soil between $66-79 \mathrm{mg} \mathrm{kg}^{-1}$, while Madejon et al. (2002) reported $55.6 \mathrm{mg} \mathrm{kg}^{-}$ ${ }^{1}$. In FA, even though $\mathrm{Zn}$ concentration was found highest amongst all seven metals (80$87 \mathrm{mg} \mathrm{kg}^{-1}$ ), it is essential for healthy growth C. dactylon.

Third important micronutrient is the $\mathrm{Cu}$, and the shoot concentration was very similar for FA and TS (12 mg kg-1), which is close to the values reported for C. dactylon in normal soil as 14-20 mg kg-1 (Shu et al., 2002) and $11.4 \mathrm{mg} \mathrm{kg}^{-1}$ (Madejon et al., 2002). The $\mathrm{Cu}$ values are within the normal range for plants $\left(3-20 \mathrm{mg} \mathrm{kg}^{-1}\right)$, and below certain level grasses able to regulate the $\mathrm{Cu}$ concentration in their tissue. Therefore, tissue concentration of $\mathrm{Mn}, \mathrm{Zn}$ and $\mathrm{Cu}$ in $C$. dactylon growing in FA and TS is of least concern, rather this plant is well adapted to the harsh conditions. Both $\mathrm{BCF}$ and TF>1 for these three elements $(\mathrm{Mn}, \mathrm{Zn}, \mathrm{Cu})$ indicates their effective accumulation and subsequent translocation of metals to the aerial parts of $C$. dactylon.

In case of other four toxic metals $(\mathrm{Cd}, \mathrm{Pb}, \mathrm{Ni}$ and $\mathrm{Co})$, their tissue level concentration were in the order of $\mathrm{Ni}>\mathrm{Pb}>\mathrm{Co}>\mathrm{Cd}$ and these metals are generally enriched in $\mathrm{FA}$ (Verma, et al., 2015). For $\mathrm{Ni}$, disposal of FA on land is the largest single input to the soil (Adriano et al., 1980). However, Ni does not consider to be highly mobile element, and its maximum concentration remains in the root. The Ni in FA does not appear to be taken by grasses in substantial amount, unlike Ni in sewage sludge (Andriano et al., 1980) due to alkaline conditions of FA. In general, bioavailable Ni concentration is found higher in FA than TS, but its translocation to the shoot is less, like $\mathrm{Pb}$ and $\mathrm{Co}$ $(\mathrm{TF}<1)$. The $\mathrm{Pb}$ concentration was higher in FA (root: $5 \mathrm{mg} \mathrm{kg}^{-1}$; shoot: $3 \mathrm{mg} \mathrm{kg}^{-1}$ ) than TS, but well within the concentration of normal soil (root: $18 \mathrm{mg} \mathrm{kg}^{-1}$; shoot: $12 \mathrm{mg} \mathrm{kg}^{-}$ ${ }^{1}$ ) (Shu et al., 2002), whereas hyperaccumulator plant has potential to accumulate more than $1000 \mathrm{mg} \mathrm{Pb}$ per kg dry wt (Reeves and Brooks, 1983). Studies showed that phytoavailability of $\mathrm{Pb}$ increase with increased level of $\mathrm{Pb}$ in soil. There is a positive significant correlation between $\mathrm{Pb}$ level in soils (EDTA- values) and in $C$. dactylon plants (Madejon et al., 2002). Most Pb uptake by plants remains in the root system and the soil-plant barrier may be protecting the food chain against $\mathrm{Pb}$ toxicity (Adriano, 1986). In the present study, the concentration of Co was found much lower for $C$. dactlylon (root: $3.5 \mathrm{mg} \mathrm{kg}^{-1}$; shoot: $2.5 \mathrm{mg} \mathrm{kg}^{-1}$ ), which is much less than the toxicity limits of $10-50 \mathrm{mg} \mathrm{kg}^{-1}$ as suggested by Kabata- Pendias and Pendias (2001). For $C$. dactylon, only four metals show $\mathrm{TF}>1$ ( $\mathrm{Mn}, \mathrm{Zn}, \mathrm{Cu}$ and $\mathrm{Cd}$ ), out of which three metals $(\mathrm{Mn}, \mathrm{Zn}$, and $\mathrm{Cu})$ are micronutrients, therefore, transferring to the aerial part is beneficial for the survival of plant. Only $\mathrm{Cd}$ is the exceptional. 
Table 3. Accumulation of metals in C. dactylon growing on fly ash and topsoil ( $\left.\mathrm{mg} \mathrm{kg}^{-1}\right)$.

\begin{tabular}{l|l|l}
\hline Metals & $\begin{array}{l}\text { C. dactylon growing on fly ash } \\
\text { (Mean } \pm \text { SD) }\end{array}$ & $\begin{array}{l}\text { C. dactylon growing on topsoil } \\
\text { (Mean } \pm \text { SD) }\end{array}$ \\
\hline $\mathrm{Mn}$ (root) & $21.60 \pm 4.55$ & $64.47 \pm 9.70$ \\
$\mathrm{Mn}$ (shoot) & $33.60 \pm 12.91$ & $34.66 \pm 7.17$ \\
$\mathrm{Zn}$ (root) & $67.04 \pm 12.18$ & $87.87 \pm 5.3$ \\
$\mathrm{Zn}$ (shoot) & $87.65 \pm 13.05$ & $80.19 \pm 7.87$ \\
$\mathrm{Cu}$ (root) & $9.81 \pm 3.90$ & $13.47 \pm 2.21$ \\
$\mathrm{Cu}$ (shoot) & $11.86 \pm 3.50$ & $11.58 \pm 2.76$ \\
$\mathrm{Ni}$ (root) & $11.47 \pm 2.93$ & $16.57 \pm 1.75$ \\
$\mathrm{Ni}$ (shoot) & $8.42 \pm 3.05$ & $8.96 \pm 1.80$ \\
$\mathrm{Cd}$ (root) & $0.76 \pm 0.45$ & $1.24 \pm 0.01$ \\
$\mathrm{Cd}$ (shoot) & $1.55 \pm 0.76$ & $1.48 \pm 0.08$ \\
$\mathrm{~Pb}$ (root) & $5.20 \pm 1.46$ & $1.52 \pm 0.03$ \\
$\mathrm{~Pb}$ (shoot) & $3.30 \pm 0.97$ & $0.37 \pm 0.11$ \\
$\mathrm{Co}$ (root) & $3.50 \pm 0.60$ & $1.54 \pm 0.12$ \\
$\mathrm{Co}$ (shoot) & $2.51 \pm 3.42$ & $0.68 \pm 0.15$ \\
\hline
\end{tabular}

Bioconcentration factor (BCF), mobility ratio (MR), and translocation factor (TF) for root and shoot of $C$. dactylon for each metal are shown in Figure $2 a, 2 b$ and $2 c$, respectively. Mobility ratio of metals in $C$. dactylon growing on FA were found in order of $\mathrm{Zn}>\mathrm{Cu}>\mathrm{Ni}>\mathrm{Mn}>\mathrm{Pb}>\mathrm{Cd}$ whereas in $\mathrm{TS}$ it was $\mathrm{Zn}>\mathrm{Cu}>\mathrm{Ni}>\mathrm{Cd}>\mathrm{Mn}>\mathrm{Pb}$. High mobility ratio of $\mathrm{Zn}$ shows higher rate of transfer of $\mathrm{Zn}$ metal from FA and TS to shoots. $\mathrm{TF}>1$ for $\mathrm{Cd}, \mathrm{Zn}, \mathrm{Mn}$, and $\mathrm{Cu}$, indicating a higher translocation of these metals in aerial parts, which can easily transfer to the food chain. TF for other metals (Ni, Co and $\mathrm{Pb}$ ) were found $<1$, shows low potential to transfer to the food chain. Translocation of metals from roots to above ground tissues is a crucial physiological process in an effective utilization of plant to remediate polluted sites.

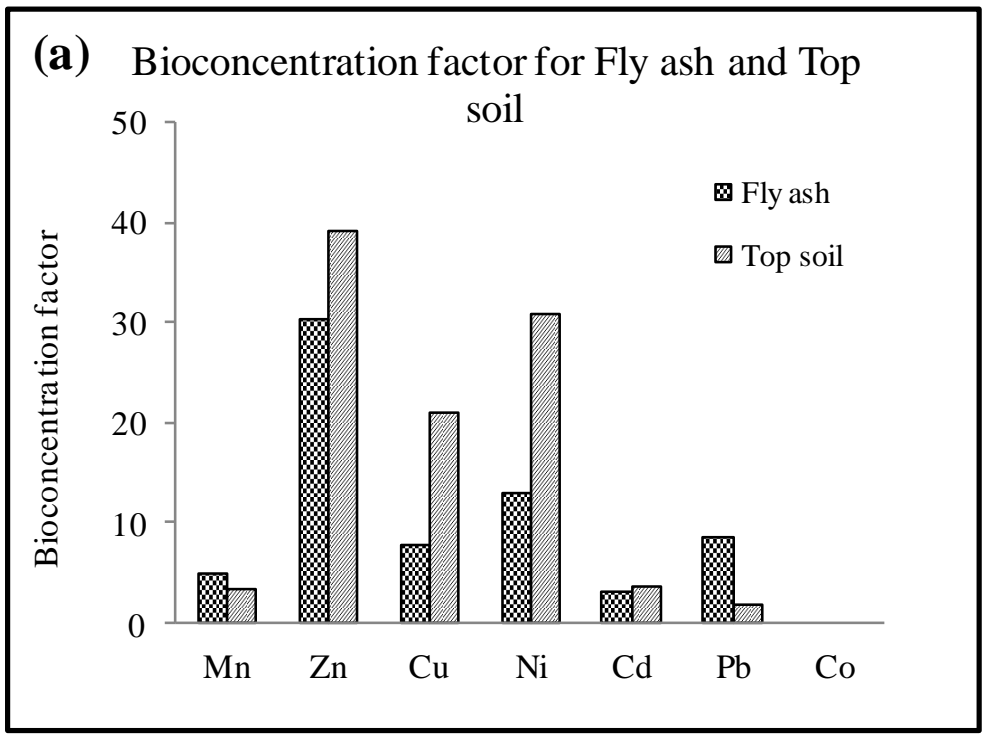


(b) Mobility ratio for Fly ash and Topsoil
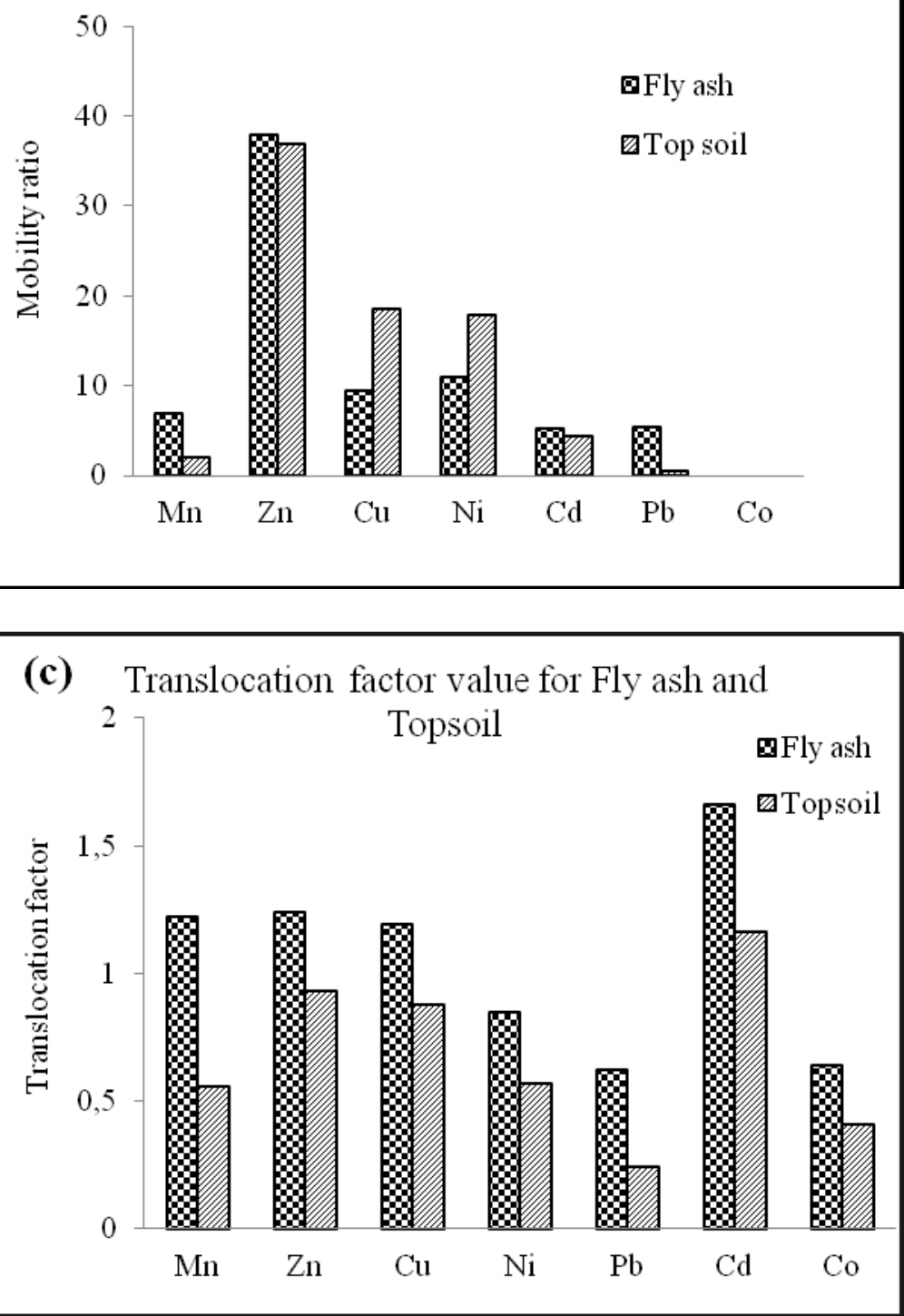

Figure 2. Comparison of (a) bioconcentration factor $(B C F)$; (b) mobility ratio $(M R)$ of DTPA extactable metals; and (c) translocation factor $(T F)$ in $C$. dactylon growing on fly ash and topsoil.

One of the most toxic metals, Cd shows highest TF in FA and TS indicate a major threat to food chain. The TF is an important criterion while selecting a plant species for phytoremediation purpose (Das and Maiti., 2007). Therefore, plant showing TF $>1$ will be considered as an accumulator plant and can be used for the phytoremediation of metals from the growing medium. The Cd shows negative correlation between DTPA$\mathrm{Cd}$ in root and shoot of FA $(\mathrm{R}=-0.461)$, which indicates $C$. dactylon grass has some internal detoxification mechanism for Cd (Figure.3). 


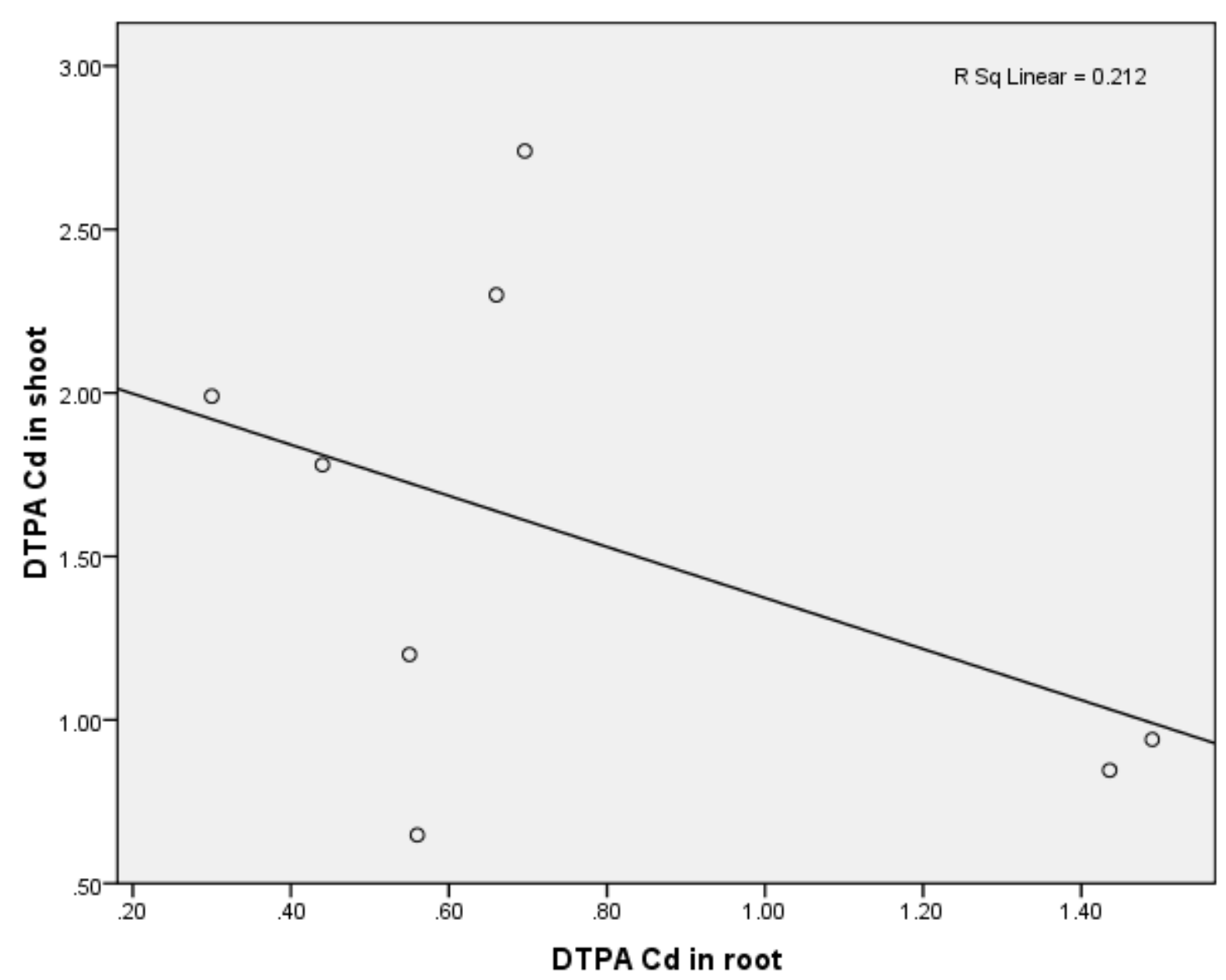

Figure 3. Regression analysis of Cd in C. dactylon (bioavailable Cd in fly ash root and shoot, concentration in $\left.\mathrm{mg} \mathrm{kg}^{-1}\right)$.

\section{Conclusions}

Blanketing of FA lagoons with topsoil not only stablize the land but also facilitates recruitment of pioneer autochthonous species (like $C$. dactylon) to develop a permanent green cover. The pioneer species eventually modify the man-made habitat and render site more suitable for the subsequent plant communities. The study concludes that $C$. dactylon is an efficient plant for the phytoremediation of FA lagoons because it has ability to accumulate toxic metal $(\mathrm{Cd})$ and micronutrient $(\mathrm{Cu}$ and some extent $\mathrm{Zn})$ as shown in the present study. The BCF, MR and TF values indicates that $C$. dactylon is a potential accumulator of the heavy metals (for $\mathrm{Ni}, \mathrm{Pb}$ and $\mathrm{Co}$ ) from FA. The study also concludes that $C$. dactylon growing on FA lagoons can act as a transferring link of heavy metal (like, Cd) in the food chain. Therefore, it is recommended that FA lagoons should be fenced to prohibit grazing of cattle.

Acknowledgement. The authors are grateful to Indian School of Mines, Dhanbad for providing necessary help during the research work. The authors are thankful to the operating staff of ESE (TK Sarkar and SP Ghosh) for analysis of metals in AAS. We also thank two anonymous reviewer for their valuable comments and suggestions. 


\section{REFERENCES}

[1] Adriano, D.C. (1986): Trace Elements in Terrestrial Environments- Biogeochemistry, Bioavailability, and Risks of Metals. Springer, New York.

[2] Adriano, D.C., Page, A.L., Elscewi, A.A., Chang, A.C., Straughan, J. (1980): Utilization and disposal of fly ash and other coal residues in terrestrial ecosystem: A review. Journal of Environmental Quality 9: 333-344.

[3] Alloway, B.J. (1990): Heavy metals in soils. John Wiley \& Sons, Inc., New York.

[4] China, S.P., Das, M., Maiti, S.K. (2014): Phytostabilization of Mosaboni Copper mine tailings: A green step towards waste management. Applied Ecology and Environmental Research 12: 25-32.

[5] Das, M., Maiti, S.K. (2007): Metal accumulation in 5 native plants growing on abandoned Cu-tailings ponds. Applied Ecology and Environmental Research 5: 27-35.

[6] FAU (2013): Fly ash Utilization- $3^{\text {rd }}$ Annual International Summit, New Delhi. Available from: http://flyash2013.missionenergy.org.

[7] Gakwavu, R.J., Sekomo, B.C., Nhapi, I. (2012): Zinc and Chromium removal mechanisms from Industrial wastewater by Water Hyacinth, Eichhornia crassipes (Mart.) Solms. Applied Ecology and Environmental Research 10: 493-502.

[8] Gupta, K.D., Rai, U.N., Tripathi, D.R., Inouhe, M. (2002): Impacts of fly ash on soil and plant responses. Journal of Plant Research 115: 401-409.

[9] Haynes, R.J. (2009): Reclamation and revegetation of fly ash disposal sites - Challenges and research needs. Journal of Environmental Management 90: 43-53.

[10] Jackson, M.L. (1973): Soil chemical analysis. PHI Pvt. Ltd., New Delhi. 183-197.

[11] Kabata-Pendias, A., Pendias, H. (2001): Trace elements in soils and plants, $3^{\text {rd }}$ ed. CRC Press, London.

[12] Keeny, D.R., Bremer, J.M. (1966): Chemical index of soil nitrogen availability. Nature 211: 892-893.

[13] Kumar, A., Maiti, S.K. (2014): Translocation and Bioaccumulation of Metals in Oryza sativa and Zea mays Growing in Chromite-Asbestos Contaminated Agricultural Fields, Jharkhand, India. Bulletin of Environmental Contamination and Toxicology 93: 434-441.

[14] Lindsay, W.L., Norvell, W.A. (1978): Development of a DTPA soil test for zinc, iron, manganese, and copper. Soil Science Society of American Journal 42: 421-428.

[15] Madejon, P., Murillo, J.M., Maranon, T., Cabrera, F., Lopez, R. (2002): Bioaccumulation of $\mathrm{As}, \mathrm{Cd}, \mathrm{Cu}, \mathrm{Fe}$ and $\mathrm{Pb}$ in wild grasses affected by the Aznalcollar mine spill (SW Spain). The Science of the Total Environment 290: 105120.

[16] Maiti, S.K. (2003): Handbook of methods in environmental studies (Vol 2): air, noise, soil and overburden analysis. ABD pub, Oxford Book Co, India.

[17] Maiti, S.K., Nandhini, S. (2006): Bioavailability of metals in fly ash and their bioaccumulation in naturally occurring vegetation: a pilot scale study. Environmental Monitoring and Assessment 116: 263-273.

[18] Maiti, S.K., Jaiswal, S. (2008): Bioaccumulation and translocation of metals in the natural vegetation growing on fly ash lagoons: a field study from Santaldih thermal power plant, West Bengal, India. Environmental Monitoring and Assessment 136: 355370.

[19] Maiti, S.K. (2013): Ecorestoration of the Coalmine Degraded Lands, Springer, NewYork.

[20] Maiti, S.K., Kumar, A., Ahirwal, J. (2015): Bioaccumulation of metals in timber and edible fruit trees growing on reclaimed coal mine overburden dumps. International Journal of Mining, Reclamation and Environment (article in press; DOI:10.1080/17480930.2015.1038864)

[21] Mukhopadhyay, S., Maiti, S.K. (2010): Phytoremediation of metal mine waste. Applied Ecology and Environmental Research 8:207-220. 
[22] Pandey, V.C., Abhilash, P.C., Upadhyay, R.N., Tewari, D.D. (2009): Application of fly ash on the growth performance and translocation of toxic heavy metals within Cajanus cajan L.: implication for safe utilization of fly ash for agricultural production. Journal of Hazardus Material 166: 255-259.

[23] Pandey, V.C., Singh, B. (2012): Rehabilitation of coal fly ash basins: Current need to use ecological engineering. Ecological Engineering 49: 190-192.

[24] Ram, L.C., Srivastava, N.K., Jha, S.K., Sinha, A.K., Masto, R.E. (2007): Management of Lignite Fly Ash for Improving Soil Fertility and Crop Productivity. Environmental Management 40: 438-452.

[25] Reeves, R.D., Brooks, R.R. (1983): Hyperaccumulation of lead and zinc by two metallophytes from mining areas of Central Europe. Environmental Pollution Series A, Ecological and Biological 31: 277-285.

[26] Sainger, P.A., Dhankhar, R., Sainger, M., Kaushik, A., Singh, R.P. (2011): Assessment of heavy metal tolerance in native plant species from soils contaminated with electroplating effluent. Ecotoxicology and Environmental Safety 74: 2284-2291.

[27] Sanghamitra, K., Prasada Rao, P.V.V., Naidu, G.R.K. (2012): Uptake of Zn (II) by an invasive weed species Parthenium hysterophorus L. Applied Ecology and Environmental Research 10: 267-290.

[28] Shu, W.S., Ye, Z.H., Lan, C.Y., Zhang, Z.Q., Wong, M.H. (2002): Lead, zinc and copper accumulation and tolerance in populations of Paspalum distichum and Cynodon dactylon. Environmental Pollution 120: 445-453.

[29] Singh, K., Pandey, V.C., Singh, R.P. (2013): Cynodon dactylon: An efficient perennial grass to revegetate sodic lands. Ecological Engineering 54: 32-38.

[30] Soleimani, M., Hajabbasi, M.A., Afyuni, M., Charkhabi, A.H., Shariatmadari, H. (2009): Bioaccumulation of nickel and lead by Bermuda grass (Cynodon dactylon) and Tall Fescue (Festuca arundinacea) from two contaminated soils. Caspian Journal of Environment Science 7: 59-70.

[31] Tripathi, R.C., Masto, R.E., Ram, L.C. (2009): Bulk use of pond ash for cultivation of wheat-maize-eggplant crops in sequence on a fallow land. Resource Conservation and Recycling 54: 134-139.

[32] Verma, S.K., Masto, R.E., Gautam, S., Choudhury, D.P., Ram, L.C., Maiti, S.K., Maity, S. (2015): Investigations on PAHs and trace elements in coal and its combustion residues from a power plant. Fuel 162: 138-147.

[33] Walkley, A., Black, I.A. (1934): An examination of the Degtjareff method for determining soil organic matter and a proposed modification of the chromic acid titration method. Soil Science 37: 29-38.

[34] Wong, M.H., Chu, L.M. (1985): Yield and metal uptake of Cynodon dactylon (Bermuda grass) grown on refuse-compost-amended soil. Agriculture, Ecosystem and Environment 14: 41-52. 